\title{
The Whitefly Dialeurodes citri: A New Pest on Citrus in Tunisia?
}

Synda Boulahia-Kheder, Université de Carthage, Institut National Agronomique de Tunisie, LR14AGR02 / Bioagresseurs et Protection Intégrée en Agriculture, 43 Av. Charles Nicolle, Cité Mahrajène,1082, Tunis, Tunisia

https://doi.org/10.52543/tjpp.16.1.2

(Tunisia)

\begin{abstract}
Boulahia-Kheder, S. 2021. The whitefly Dialeurodes citri: a new pest on citrus in Tunisia? Tunisian Journal of Plant Protection 16 (1): 11-18.

Whiteflies invaded citrus orchards in Tunisia in the 90's. Two species: Aleurothixus floccosus and Parabemisia myricae have been recorded successively infesting citrus and causing severe damage in Cap-Bon (North-East of Tunisia). These pests were first controlled by several insecticidal applications but with a relative efficiency. Then two biological control programs have been deployed completing the action of native natural enemies especially for $P$. myricae. The result was a very satisfactory control of both whitefly species, to a point that they almost disappeared from orchards for about 30 years. In 2017, a third whitefly species, identified as Dialeurodes citri, was observed during a prospection in citrus orchards in Takelsa region (Cap-Bon). It was a common species in Algeria, but never caused damage in Tunisia. In 2020, D. citri was found again with very high population densities in the regions of Menzel Bou Zelfa (Cap-Bon) and Tunis. These observations confirmed its change of status and spread in Tunisia. The main morphological and biological traits to distinguish between D. citri and the other two whitefly species, already recorded in Tunisia, were described and first observations on its infestation were reported. Some recommendations to manage this new pest are given.
\end{abstract}

Keywords: Biology, citrus, Dialeurodes citri, morphology, natural enemies, whiteflies

\section{Introduction}

Whiteflies (Hemiptera: Aleyrodidae) are economically important insect pests (Hodges and Evans 2005) that cause damage by two ways: through sucking plant sap inducing weakening of plants and for some species through transmission of viruses. Under favorable conditions, whitefly populations can develop high densities in few weeks producing a large amount of honeydew (with more or less waxy secretions) and sooty mold which by soiling the production, seriously reduces its value (Mound and Halsey 1978). In the Mediterranean region including Tunisia, different species of whiteflies caused severe damage during 70-90's (Boulahia-Kheder 1993; Dhouibi and Jerraya 1991a; Onillon 1975; Uygun et al. 1990). Since 2000's the whiteflies were not considered as economically important citrus pests (Garcia-Mari et al. 2018).

Corresponding Author: Synda Boulahia-Kheder

Email: synda.kb@gmail.com

Accepted for publication 21 January 2021
In Tunisia, two whitefly species had invaded citrus orchards in the 90's causing severe damage (Chermiti et Onillon 1992; Dhouibi and Jerraya, 1991b). The first one introduced, was the woolly whitefly, Aleurothixus floccosus in 1988 (Jerraya 2003). Several insecticides were sprayed but had a relative efficacy. A national program of biological control that imported and released the parasitoid species Cales noaki, was a sustainable solution (Chermiti et Onillon 1993). The biological control was so successful that $A$. floccosus completely disappeared from citrus orchards. However, in 1990-91, A. floccosus was quickly displaced by the Japanese or bayberry whitefly, Parabemisia myricae, that reached very high densities on citrus and caused severe damage (Chermiti et Onillon 1992; Kheder-Boulahia1993). This polyphagous whitefly species was also found on pomegranate mixed with citrus, on grapes (Vitis sp.) as well as on weeds Mercurialis annua and Malva sylvestris (Kheder-Boulahia 1993). About one year after its introduction, it was partially controlled by the native parasitoid, Encarsia 
transvena (Chermiti et Onillon 1992; KhederBoulahia 1993). Concomitantly in 1993, the parasitoid Eretmocerus debachi was introduced and released in citrus orchards against $P$. myricae (Chermiti et al. 1995). Three years later, $P$. myricae was controlled biologically and "the problem of whiteflies on citrus" was overcame for more than 20 years, as both species were very difficult to found in citrus groves. In 2017, some phytosanitary prospections in the Cap-Bon region (North-East of Tunisia) reported the whitefly Dialeurodes citri that was not considered as a pest on citrus in Tunisia before (Kheder-Boulahia et Jerraya 1995a). Indeed, although D. citri was reported by Martin et al. (2000) as present in Tunisia, it has never caused damage requiring phytosanitary interventions. D. citri was detected once in Takelsa region (Cap-Bon) in 2017 (Dahri 2017) and again in February 2020, in the region of Menzel Bou Zelfa (Cap-Bon) in 2 orchards and in a private garden in Tunis, with high densities. In other Mediterranean countries such as Algeria, France and Turkey, D. citri was a common species since a long time (Boukhlafa et Bonafonte 1979; Onillon et al. 1975; Uygun et al. 1990). In addition to its direct damage, it was demonstrated recently that $D$. citri can transmit virus to citrus namely the citrus yellow vein clearing virus (CYVCV), an emerging citrus virus, to lemon trees (Zhang et al. 2019). Whiteflies still represent a threat to citrus production in Mediterranean conditions as new species are regularly reported. Indeed, recently in Algeria, Malta, Italy and most of the Mediterranean countries, except Tunisia, a new species of whitefly, Paraleyrodes minei has been reported on citrus (Ben MessaoudBoukhalfa and Chebrou 2014; Longo and Rapisarda 2014; Malumphy and Mifsud 2016).

In this paper, some data related to first observations on D. citri in Tunisia were reported. Morphological and behavioral traits of D. citri in comparison with A. floccosus and $P$. myricae to facilitate the distinction among the 3 species for a field worker were provided. Finally, recommendations to implement a control strategy against this new pest were proposed.

Morphology and behavior of $D$. citri compared with $A$. floccosus and $P$. myricae.

The first step of an appropriate program to control whiteflies is a precise identification of the pest because each species has different biology, population dynamic and natural enemy complex. Hence, it is important to distinguish between $D$. citri and the 2 other species present in Tunisia on citrus: A. floccosus and $P$. myricae. This can be achieved based on criteria visible in the field, but a precise identification requires microscopic preparations.

For a rapid identification in the field, the most evident difference between the 3 species is the dorsal waxy secretion of the $4^{\text {th }}$ nymphal instar, which is thin, transparent, and amorphous for D. citri (Ben MessaoudBoukhalfa 1987) (Fig. 1), opaque white, thick and woolly with long waxy filaments visible to the naked eye for A. floccosus, and translucent with extremely thin transparent marginal wax for P. myricae (Gerling 1990; KhederBoulahia1993; Kheder-Boulahia et Jerraya 1995a). Once the $4^{\text {th }}$ instar completes its development, the adult emerges from the pupal case leaving a specific shape: " $\mathrm{T}$ " for $D$. citri and A. floccosus (Fig. 1) (Ben MessaoudBoukhalfa 1987; Onillon et Abbassi 1973) and an irregular aperture for $P$. myricae (Uygun et al. 1990).

Although whitefly adults are very similar, they have some characters that allow an experimented observer to recognize the 3 species. The wings of $D$. citri are unmarked and often held relatively flat with a distinct interstice between them (Uygun et al. 1990). The adults of $P$. myricae have no marks on pearl-colored wings. The adults of A. floccosus have uniformly white wings (Dreistadt 2012).

Also, the egg arrangement and the preferred age of leaves for egg-laying allow to separate the 3 species in the field: for $D$. citri and $P$. myricae, their eggs are scattered by an irregular way on leaves (Fig. 1), while for $A$. floccosus, the eggs are often inserted in the form of circles or half-circles. Whiteflies are known to oviposit mainly on growing leaves, but there are differences in the preferred age between the 3 species, which can be a criterion of distinction among them in the field. P. myricae strongly prefers the very young leaves, that are tender and unexpanded (Kheder-Boulahia et Jerraya 1995b; Walker and Zareh 1990) and most of eggs (72.2\%) are laid on the 4 apical leaves on twigs (Kheder-Boulahia et Jerraya 1995b). For D. citri and A. floccosus, rather mature leaves fully expanded are the preferred egg-laying sites 
(Ben Messaoud-Boukhalfa1987; Walker and Zareh 1990). At the leaf-scale, there are also differences among the 3 whitefly species. Most of eggs are laid on the lower face for $A$. floccosus, and especially for D. citri. However, for P. myricae, more than $90 \%$ of eggs are inserted on the upper face, and once emerged, the first instar larvae migrate to the lower face where they settle definitely. This behavior can change when very high infestation occurs (more than 2000 eggs/leaf) with both faces of leaves hosting approximately the same number of eggs (Kheder-Boulahia et Jerraya 1995b). Finally, the color and position of eggs are different: erected eggs, white then blackish for $P$. myricae; inserted in an angle to leaf, white or pale-yellow then brownish or orange, respectively for $D$. citri (Fig. 1) and A. floccosus (Dhouibi and Jerraya 1991b; Kheder-Boulahia 1993; Uygun et al. 1990; Zanic et al. 2000).

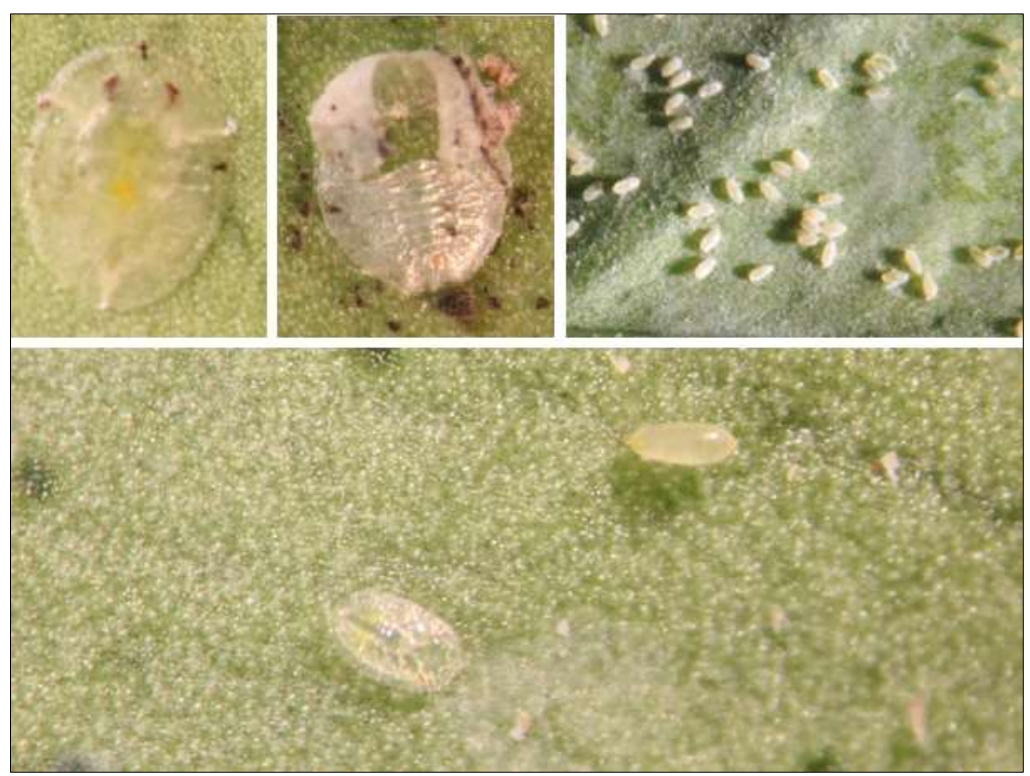

Fig. 1. Dialeurodes citri on citrus. Top: Fourth nymphal instar (left), puparial case (middle) and egg arrangement (right) (magnification: $\times 120$ ); Bottom: Enlarged egg and crawler (magnification: $\times 200)$.

For precise identification of whitefly species, microscopic characters related to the $4^{\text {th }}$ nymphal instar or puparium have to be observed (Hodges and Evans 2005; Martin et al. 2000; Mound and Halsey 1978). The most important is the structure of vasiform orifice unique to aleyrodids (Martin et al. 2000) and its operculum and lingula, that allow to identify the genera and species. Vasiform orifice has 2 morphologies: one with operculum completely filling the orifice, so the lingula is hidden in dorsal view (case of $A$. floccosus and D. citri), the second with operculum not filling the posterior part of the orifice, and so with a visible lingula (case of P. myricae) (Gerling 1990) (Table 1, Fig. 2).

Other microscopic characters to distinguish the $1^{\text {st }}$ stage and adults related to the antennae and metatibial chaetotaxy of the female and structure of male genitalia were described by Kheder-Boulahia et Jerraya (1995a), while there are very few available taxonomic characters of other stages than the $4^{\text {th }}$ instar (Hodges and Evans 2005). 
Table 1. Microscopic characters of $4^{\text {th }}$ instar of Dialeurodes citri, Aleurothixus floccosus and Parabemisia myricae (Ben Messaoud-Boukhalfa 1987; CABI 2020; Dreistadt 2012; Hodges and Evans 2005; Kheder-Boulahia 1993; Kheder-Boulahia et Jerraya 1995a)

\begin{tabular}{|c|c|c|c|}
\hline \multirow{2}{*}{ Microscopic features } & \multicolumn{3}{|c|}{ Species of whiteflies } \\
\hline & Dialeurodes citri & Aleurothixus floccosus & Parabemisia myricae \\
\hline $\begin{array}{l}\text { Body color and } \\
\text { specific character }\end{array}$ & $\begin{array}{l}\text { Colorless or yellowish } \\
\text { Tracheal folds ( } 2 \text { thoracic and } 1 \\
\text { abdominal) lined with spinules, } \\
\text { densely alveolar and delineating } \\
\text { "Y" shape. }\end{array}$ & Orange brown & Light yellow \\
\hline $\begin{array}{l}\text { Vasiform orifice } \\
\text { (VO), Operculum (O) } \\
\text { and Lingula (L) }\end{array}$ & $\begin{array}{l}\text { Sub-circular, relatively small and } \\
\text { with a broad rim. Operculum, } \\
\text { almost filling the VO concealing } \\
\text { the tip of the lingula. O with } \\
\text { droplet-shaped expansions at its } \\
\text { tip (observed under an electron } \\
\text { microscope on winter larvae. } \\
\text { These expansions are longer on } \\
\text { winter larvae than on summer } \\
\text { larvae. }\end{array}$ & $\begin{array}{l}\text { Semi-circular, } \\
\text { hidden }\end{array}$ & $\begin{array}{l}\text { In a stretched isosceles } \\
\text { triangle, lingula with } 2 \text { sub- } \\
\text { median blunt-end tubercles } \\
\text { and } 1 \text { rounded posterior } \\
\text { tubercle with } 2 \text { long lingular } \\
\text { setae }\end{array}$ \\
\hline Profile & Very flattened & Fairly thick & Flattened \\
\hline Caudal margin & Finely crenellated & Serrated & Finely corrugated \\
\hline $\begin{array}{l}\text { Caudal marginal } \\
\text { setae }\end{array}$ & $\begin{array}{l}2 \text { short and rigid setae on a bud- } \\
\text { like structure on either side of the } \\
\text { upper edge of VO (observed } \\
\text { under an electron microscope on } \\
\text { winter larvae; these setae } \\
\text { correspond probably to } \\
\text { abdominal setae) }\end{array}$ & $\begin{array}{l}2 \text { long and thick abdominal } \\
\text { setae and } 2 \text { long and thick } \\
\text { caudal setae }\end{array}$ & $\begin{array}{l}2 \text { caudal setae and } 2 \text { posterior } \\
\text { setae }\end{array}$ \\
\hline $\begin{array}{l}\text { Waxy pores and } \\
\text { porettes }\end{array}$ & & $\begin{array}{llr}\text { Conical wax } & \text { cells } \\
\text { comprised } & \text { of } 2-3 & \text { waxy } \\
\text { pores } & & \end{array}$ & $\begin{array}{l}\text { About } 120 \quad \text { porettes } \\
\text { uniformly dispersed on the } \\
\text { larvae body drawing } 4 \text { ellipse } \\
\text { arcs from the anterior to the } \\
\text { posterior region }\end{array}$ \\
\hline
\end{tabular}

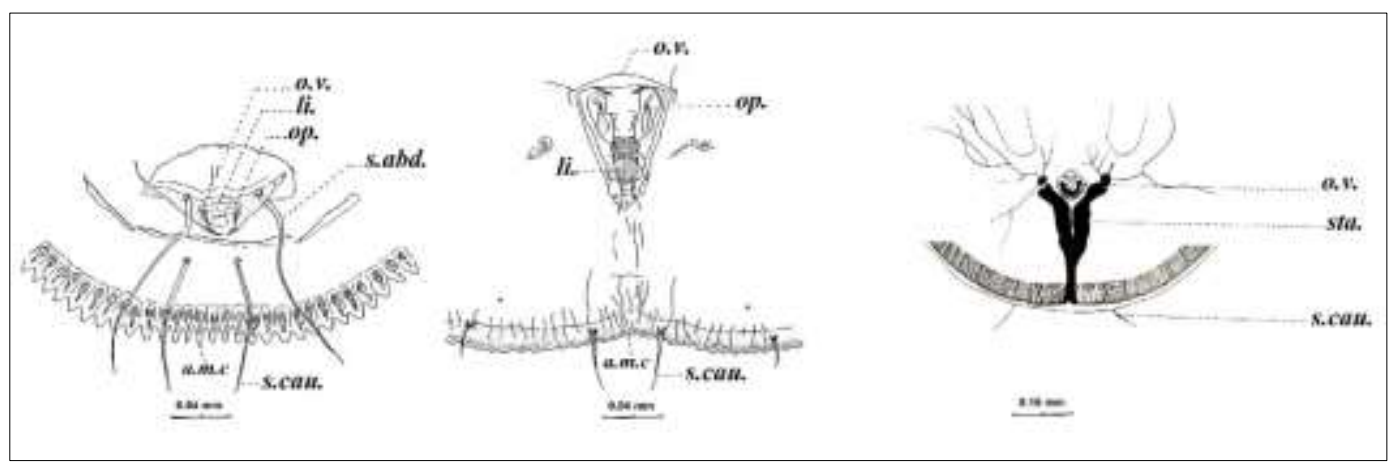

Fig. 2. Slide-mounted vasiform orifices of $4^{\text {th }}$ instar of Aleurothixus floccosus (left), Parabemisia myricae (middle) and Dialeurodes citri (right). a.m.c.: caudal marginal area, li.: lingula, op.: operculum, o.v.: vasiform orifice, s. abd.: abdominal setae, s.cau.: caudal setae, sta.: tracheal abdominal fold. (Ben Messaoud-Boukhalfa 1987; Kheder-Boulahia 1993; KhederBoulahia et Jerraya 1995a). 
Biological traits of $D$. citri.

D. citri was reported from various locations in the world as a multivoltine species that can accomplish many generations per year: 2-3 in Algeria, 3 in Israel and Croatia, 2-6 in California (USA) (Argov et al. 2000; Bellows and Meisenbacher 2007; Ben MessaoudBoukhalfa 1987; Zanic et al. 2001). In Israel, the $1^{\text {st }}$ and $2^{\text {nd }}$ generations, which occurred between spring and summer had an average duration from egg to adult of $58.35 \pm 15.85$ days in the field (Argov et al. 1999). In Tunisia, warm climatic conditions may produce more than 3 generations per year for $D$. citri.

D. citri prefers interior of the tree, followed by the shaded sides for oviposition and development (Argov et al. 1999). D. citri has a high fecundity with an average 150 eggs/female and a great growth rate $\left(R_{0}=15\right)$. In California, in spring and autumn, leaves of 'Valencia Late' oranges were entirely covered by adults of $D$. citri laying more than 3000 eggs/leaf (Bellows and Meisenbacher 2007). In Algeria also, the density of eggs reached 3000 eggs $/ \mathrm{dm}^{2}$ in spring on clementine (Ben Messaoud-Boukhalfa 1987). Moreover, D. citri is a polyphagous pest as it attacks citrus and more than 70 plant species belonging to 30 families (Mound and Halsey 1978) with a preference for Citrus spp. in the Mediterranean countries (Uygun et al. 1990). In Croatia, Jasminum spp. and Dyospiros kaki were the most infested hosts other than citrus, while in Italy D. citri infested several Oleaceae plants but not the citrus (Zanic et al. 2001).

\section{Current infestation and damage of $\boldsymbol{D}$. citri.}

In 2017, D. citri was found in a citrus orchard in the region of Takelsa (36 $46^{\prime} 59.99^{\prime \prime}$ $\left.\mathrm{N} 10^{\circ} 37^{\prime} 59.99^{\prime \prime} \mathrm{E}\right)$ on spring flushes with a fairly high density of adults (Fig. 3) and eggs with an average of about 82 eggs/leaf and a maximum of 515 eggs. In 3 weeks, infestation rate increased significantly from 36 to reach $100 \%$ (Table 2) (Dahri 2017). In 2020, a very severe infestation was observed in the region of Menzel Bou Zelfa, $\left(36^{\circ} 40^{\prime} 54.12^{\prime \prime} \mathrm{N}\right.$ $\left.10^{\circ} 35^{\prime} 4.92^{\prime \prime} \mathrm{E}\right)$ where the attacked leaves and twigs were completely covered by sooty mold (Fig. 3). These observations confirmed the great biotic potential of this whitefly due to its high fecundity and great growth rate (Bellows and Meisenbacher 2007).

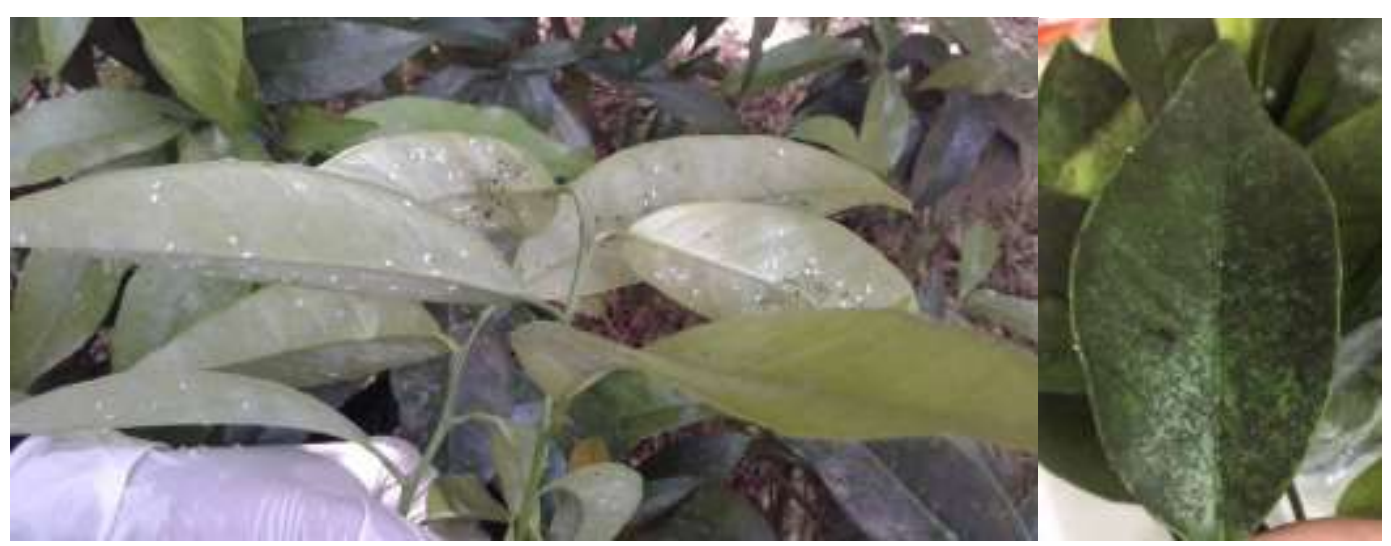

Fig. 3. On the left, adults of Dialeurodes citri on citrus spring flushes (Takelsa, May 12 ${ }^{\text {th }}$ 2017) (Dahri 2017). On the right, our observation of citrus leaf of autumn flush with a heavy sooty mold (Menzel BouZelfa).

Table 2. Infestation level of Dialeurodes citri on citrus spring flushes in Takelsa (Dahri 2017)

\begin{tabular}{c|cccc}
\hline Date & $\begin{array}{c}\text { No. of infested leaves/N. } \\
\text { of examined leaves }\end{array}$ & No. of eggs & $\begin{array}{c}\text { Density of } \\
\text { eggs/leaf }\end{array}$ & $\begin{array}{c}\text { Rate of } \\
\text { infestation (\%) }\end{array}$ \\
\hline $\mathbf{2 1 - 0 4}$ & $18 / 50$ & 367 & 7.34 & 36 \\
\hline $\mathbf{1 2 - 0 5}$ & $150 / 150$ & 12297 & 81.98 & 100 \\
\hline
\end{tabular}


Some observations on natural regulation of D. citri and recommendations for control.

First observations showed that in some orchards, D. citri was associated with some predators which would be promising for future trends of this whitefly population. Larvae of Chrysopidae and Coccinellidae presumably Clitostethus arcuatus, were observed predating on $4^{\text {th }}$ instar and eggs of D. citri (Dahri 2017). C. arcuatus was reported as a very efficient egg and $\mathrm{L}_{1}$ predator in particular climatic conditions (Ben Messaoud-Boukhalfa 1987; Liotta 1978 in Ben Messaoud-Boukhalfa1987). Other predators such as the thrips Aeolothrips faciapennis, mites, several coccinellids and spiders were found associated with D. citri (Bellows and Meisenbacher 2007; Mound and Halsey 1978; Ulusoy et al. 1996). In our observations, no parasitism has been detected while in Taiwan 5 species of parasitoids have been reported (Bellows and Meisenbacher2007) and Mound and Halsey (1978) reported 7 species of Aphelinidae, mostly of the Prospaltella genus. In addition to entomophagous insects, diseases and especially the fungi Aschersonia sp., were recorded as significant general regulators against $D$. citri (Bellows and Meisenbacher 2007).

In natural ecosystems, whiteflies are usually maintained under control by parasitoids and predators, while in agricultural crops natural balance is often broken by abusive use of chemicals leading to consistent populations of whiteflies (Hodges and Evans 2005). Many environmentally friendly methods can be employed against whiteflies. In Turkey and Israel where $D$. citri was reported since the 6070 's biological and integrated control combining cultural practices such as thorough pruning, weed removing and summer applications of mineral oil, were successfully used to control this pest (Argov et al. 2000; Uygun et al. 1990). In Turkey, the orchards under integrated pest management were less infested than those with heavy use of pesticides (Ulusoy et al. 1996).

In Tunisia, natural enemies currently associated with $D$. citri and their regulatory action, have to be determined. Also, the use of pesticides against the other citrus pests should be reasoned to preserve beneficial insects and to avoid outbreaks of $D$. citri as this whitefly seems to be a problem of pest resurgence. Indeed in recent years, D. citri has started to increase seriously in several locations very likely due to abusive use of pesticides (Dahri 2017; Dahri and Boulahia-Kheder 2017).

\section{Conclusion.}

Recently, the whitefly species, $D$. citri changed its pest status and can be added to the two other species that caused severe damage in Tunisia in years 90's: A. floccosus and $P$. myricae. Due to its high reproductive rate, $D$. citri is expected to be a serious pest species on citrus. Consequently, survey and ecological studies of $D$. citri are highly required in order to establish an integrated pest control strategy. However, environmentally friendly measures to maintain populations of $D$. citri under threshold and to limit its spread can already be recommended: cultural practices and use of less hazardous insecticides such as mineral oils.

\footnotetext{
Acknowledgments.

The author is grateful to Dr. Essia Limen and to Mrs. Mounira Ben Amara (General Directorate of Plant Health and Control of Agricultural Inputs / Ministry of Agriculture, Tunisia) for their help in field visits.
}

\section{RESUME \\ Boulahia-Kheder S. 2021. L'aleurode Dialeurodes citri: un nouveau ravageur des agrumes en Tunisie? Tunisian Journal of Plant Protection 16 (1): 11-18.}

Les aleurodes des agrumes ont envahi la Tunisie dans les années 90. Deux espèces avaient successivement colonisé les vergers d'agrumes du Cap-bon (Nord-Est Tunisien) et causé d'importants dégâts. Il s'agissait de l'aleurode floconneux des agrumes Aleurothixus floccosus et l'aleurode japonais Parabemisia myricae. Ces deux aleurodes ont d'abord été combattus par des applications insecticides répétées mais avec une efficacité relative. Puis deux programmes de lutte biologique ont été déployés complétant l'action des ennemis naturels autochtones notamment pour $P$. myricae, ce qui a permis un contrôle très efficace, au point où ces ravageurs ont quasi disparu des vergers d'agrumes pendant environ 30 ans. En 2017, lors d'une prospection dans la région de Takelsa (Cap-Bon), une $3^{\text {ème }}$ espèce d'aleurode a été observée. Il s'agissait de Dialeurodes citri, espèce commune en Algérie. En Tunisie, bien que signalée, $D$. citri n'a jamais été considérée comme une espèce préoccupante sur les agrumes puisqu'aucun dégât ne lui a été attribué. Cet aleurode a été de nouveau trouvé en 2020 avec des densités très élevées dans les régions de Menzel Bou Zelfa (Cap-Bon) et de Tunis. Ces observations confirment le changement de statut et la propagation de 
D. citri en Tunisie. Dans la présente note sont décrits les principaux critères morphologiques et comportementaux permettant la distinction de $D$. citri des autres espèces d'aleurodes présentes en Tunisie ainsi que les premières observations relatives à son infestation. Quelques orientations pour gérer ce nouveau ravageur sont proposées.

Mots-clés: Agrumes, aleurodes, biologie, Dialeurodes citri, ennemis naturels, morphologie

\section{بولحية_خذر، سندة. 2021. الذبابة البيضاء Dialeurodes citri: آفة جليدة على القوارص/الحمضيات في تونس؟} Tunisian Journal of Plant Protection 16 (1): 11-18.

تعرّضت البلاد التونسية في التسعينات إلى غزو من أنواع الذبابة البيضاء التى تصيب القوارص/الحمضيات، و احتلت نوعان من هذه

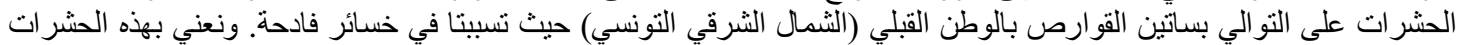
الذبابة البيضاء القطنية للقو ارص Aleurothrixus floccosus و الذبابة البيضاء اليضي اليابانية Parabemisia myricae.

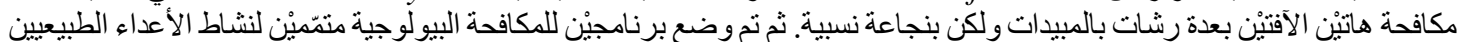

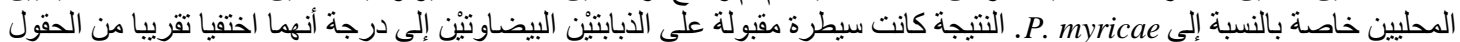

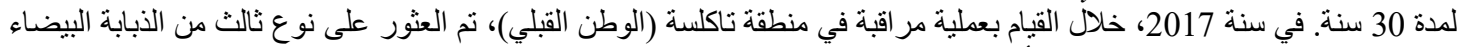

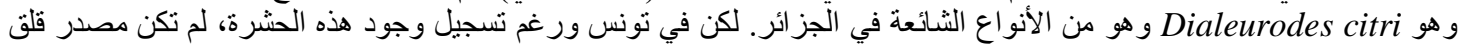

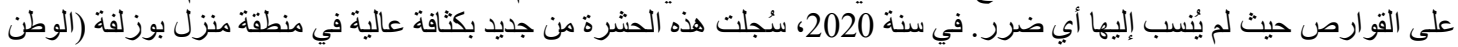

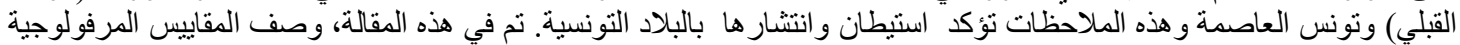

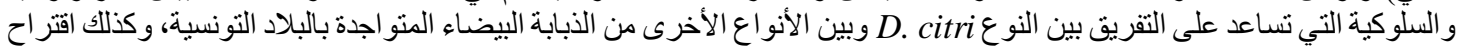
بعض التوجيهات لمكافحة هذه الآفة الجديدة. لئن التوع

كلمات مفتاحية: أعداء طبيعيين، بيولوجيا، ذبابة بيضاء، قوارص/حمضيات، مورفولوجيا، Dialeurodes citri

\section{LITERATURE CITED}

Argov, Y., Rossler, Y., Voet, H., and Rosen, D. 1999. The biology and phenology of the citrus whitefly, Dialeurodes citri on citrus in the Coastal Plain of Israel. Entomologia Experimentalis et Applicata 93:21-27.

Argov, Y., Rossler, Y., Voet, H., and Rosen, D. 2000. Introducing Encarsiala horensis against Dialeurodes citri in Israel: a case of successful biological control. BioControl 45: 1-10.

Belaam-Kort, I., Marullo, R., Attia, S., and BoulahiaKheder, S. 2020. Thrips fauna (Insecta, Thysanoptera) in citrus orchards in Tunisia: an up-to-date. Bulletin of Insectology 73 (1): 1-10.

Bellows, T.S., and Meisenbacher, Jr.C. 2007. Field population biology of citrus whitefly, Dialeurodes citri (Ashmead) (Heteroptera: Aleyrodidae), on oranges in California. Popul. Ecol. 49: 127-134. (DOI 10.1007/s10144-006-0028-y)

Ben Messaoud-Boukhalfa, H. 1987. Bioécologie de l'aleurode des agrumes: Dialeurodes citri (Ash.) (Homoptera: Aleyrodidae) dans un verger de clémentiniers en Mitidja. Thèse de Magister en Sciences Agronomiques, Institut National Agronomique d'El Harrach, Alger, Algeria, 102 pp.

Ben Messaoud-Boukhalfa, H., and Chebrou, S. 2014. Etude préliminaire de la bioécologie de Paraleyrodes minei laccarino 1990 (Homoptera : Aleyrodidae: Aleyrodicinae), nouvel aleurode des Citrus en Algérie. 6 pp. In: Proceedings of AFPP International Conference on Invasive and Emerging Pests and Insects. October 21, 2014, Montpellier, France.

Boukhalfa, H., and Bonafonte, P. 1979. Observations des populations de l'aleurode des Citrus, Dialeurodes citri Ashmead (Hom., Aleurodidae) dans la plaine de la Mitidja (Algérie), pendant la période hivernale et posthivernale. Fruits 34 (1): 43-52.

CABI, 2020. Invasive species compendium. Datasheet: Dialeurodes citri (citrus whitefly). https://www.cabi.org/isc/data sheet/18698\#REFDDB-183911 (accessed on September 15 ${ }^{\text {th }}, 2020$ ).

Chermiti, B., et Onillon, J-C. 1992. A propos de la présence en Tunisie de deux nouvelles espèces d'aleurodes nuisibles aux agrumes, Aleurothrixus floccosus (Maskell) et Parabemisia myricae (Kuwana) (Homoptera, Aleurodidae). Fruits 47 (3): 405-411.

Chermiti, B., and Onillon, J-C. 1993. Control of the woolly whitefly Aleurothrixus floccosus (Homopt., Aleurodidae) by the parasitoid Calesnoaki (Hymenopt., Aphelinidae). https://www.researchgate. net/publication/261877590 (accessed on October $20^{\text {th }}$, 2020).

Chermiti, B., Gahbiche, H., Onillon, J-C., and Laarif, A. 1995. Introduction et acclimatation en Tunisie d'Eretmocerus debachii Rose et Rosen (Hym., Aphelinidae) parasitoide de Parabemisia myricae Kuwana (Hom., Aleurodidae). https://www.researchgate.net/publication/261877853 (accessed on October $20^{\text {th }}, 2020$ ).

Dahri, A. 2017. Contribution à l'étude de l'entomofaune des Citrus en Tunisie. Projet de Fin d'Etudes du Cycle Ingénieur, Institut National Agronomique de Tunisie, Université de Carthage, Tunis, Tunisia,74 pp.

Dahri, A., and Boulahia-Kheder, S. 2017. Le pou rouge de Californie Aonidiella aurantii (Hemiptera, Diaspididae) sur Citrus en Tunisie: Insecte anodin ou envoie de devenir économiquement important? Page 180. In: Abstract book of First Maghreb Symposium on Integrated Plant Protection (SYMPIP 2017). October 30-November $1^{\text {st }}$, 2017, Sousse, Tunisia.

Dhouibi, M.H. and Jerraya, A. 1991a. La mouche blanche des agrumes, Aleurothrixus floccosus Mask. Doc Technique. Institut National agronomique de Tunisie, Tunisia, $24 \mathrm{pp}$.

Dhouibi, M.H., and Jerraya, A. 1991b. Essai de traitement contre la mouche blanche des agrumes Aleurothrixus 
floccosus Mask. (Homoptera: Aleyrodidae). Med. Fac. Landbouwn. RijkSuniv. Gent., 56/3b: 1129-1142.

Dreistadt, S.H. 2012. Integrated Pest Management for Citrus. Third Edition, University of California, Division of Agriculture and Natural Resources, USA, $270 \mathrm{pp}$.

Garcia-Marí, F., Ammad, F., Armengol Forti, J., Aroun, M.E.F., Belguendouz, R., Benfekih, L., Bounaceur, F., Chermiti, B., Conti, F., Entrudo Fernandes, J., Carlos Franco, J., Giannakou, I., Kapaxidi, E., Kormpi, M., Markellou, E., Boukhalfa R., Razi, S., Satar, S., Siscaro, G., Smaili, M.C., Soares, C., Tzortzakakis E., and Varikou, K. 2018. Questionnaire on the current situation of citrus pests and diseases in the Mediterranean basin. IOBC-WPRS Bulletin Integrated Control in Citrus Fruit Crops 132: 2-5.

Gerling, D. 1990. Whiteflies: Their Bionomics, Pest status and Management. Intercept Ltd, Andover Hants, UK, $349 \mathrm{pp}$.

Hodges, G.S., and Evans, G.A. 2005. An identification guide to the whiteflies (Hemiptera: Aleyrodidae) of the South-Eastern United States. Florida Entomologist 88 (4): 518-534.

Jendoubi, H., Grissa, K.L., Suma, P., and Russo, A. 2008. Scale insect fauna (Hemiptera, Coccoidea) of citrus in Cap Bon region (Tunisia). Bulletin IOBC/wprs, Control in Citrus Fruit Crops 38: 87-93.

Jendoubi, H. 2018. The scale insect fauna of citrus in Tunisia: A critical overview. International Journal of Fauna and Biological Studies 5 (3): 169-178.

Jerraya, A. 2003. Principaux nuisibles des plantes cultivées et des denrées stockées en Afrique du Nord. Leur biologie, leurs ennemis naturels, leurs dégâts et leur contrôle. Climat Pub, Ed. Tunisia, 415 pp.

Kheder-Boulahia, S. 1993. Etude des aleurodes dans un verger agrumicole du Cap-Bon et plus particulièrement de Parabemisia myricae (Kuwana) (Homoptera : Aleyrodidae). Mémoire de Fin de Cycle de Spécialisation, Institut National Agronomique de Tunisie, Université de Carthage, Tunis, Tunisia, 153 pp.

Kheder-Boulahia, S., and Jerraya, A. 1995a. Comparative morphology of four species of whiteflies present in Citrus orchard (Cap-bon, Tunisie). Annals of INRAT 68: 71-92.

Kheder-Boulahia, S., and Jerraya, A. 1995b. On the oviposition behavior of Parabemisia myricae Kuw. (Hom: Aleyrodidae). Annals of INRAT 68: 93-102.

Longo, S., and Rapisarda, C. 2014. Spread of Paraleyrodes minei Iaccarino (nesting whitefly) in Italian citrus groves. EPPO Bulletin 44 (3): 529-533.

Malumphy, C., and Mifsud, D. 2016. First record of the nesting whitefly, Paraleyrodes minei Iaccarino, 1990 (Hemiptera, Aleyrodidae) in Malta. Bull. Ent. Soc. Malta 8: 90-93.

Martin, J.H., Mifsud, D., and Rapisarda, D. 2000. The whiteflies (Hemiptera: Aleyrodidae) of Europe and the
Mediterranean Basin. Bulletin of Entomological Research90: 407-448.

Mound, L.A., and Halsey, S.H. 1978. Whitefly of the world. A systematic catalogue of the Aleyrodidae (Homoptera) with host plant and natural enemy data. British Museum (Natural History) and John Wiley and Sons, Chichester-New York - Brisbane-Toronto, USA, $340 \mathrm{pp}$.

Onillon, J-C. 1973. Possibilités de régulation des populations d'Aleurothrixus floccosus Mask. (Homopt., Aleurodidae) sur agrumes par Calesnoaki How. (Hymenopt., Aphelinidae). OEPP/EPPO Bulletin 3 (1): 17-26.

Onillon, J-C. 1975. Contribution à l'étude de la dynamique des populations d'Homoptères inféodés aux agrumes. V.3. Evolution des populations d'A. floccosus (Homopt., Aleurodidae) pendant les 3 années suivant l'introduction de $C$. noaki How. (Hyménopt., Aphelinidae). Fruits 30 (4) : 237-245.

Onillon, J-C., and Abbassi, M. 1973. Notes bioécologiques sur l'aleurode floconneux des agrumes Aleurothrixus floccosus MASK. (Homopt., Aleurodidae) et moyens de lutte. Al-Awamia 49 : 99-116.

Onillon, J-C., Onillon, J., et Brun, P. 1975. Contribution à l'étude de la dynamique des populations d'Homoptères inféodés aux agrumes. II-3- Premières observations sur l'évolution comparée des populations de Dialeurodes citri (ASHMEAD) (homopt. aleurodidae) en Corse et dans le sud-est de la France. Fruits 30 (3) : 167-171.

Trabelsi,I.,and Boulahia-Kheder, S.2009. Sur la présence en Tunisie du thrips des agrumes Pezothrips kellyanus (Thysanoptera: Thripidae). Annales de 1'INRAT 82: 181-186.

Ulusoy, M.R., Uygun, N., Kersting, U., Karaca, I., and Satar, S. 1996. Present status of citrus whiteflies (Homoptera: Aleyrodidae) in Turkey and their control. Journal of Plant Diseases and Protection 103 (4): 397 402.

Uygun, N., Ohnesorge, B., and Ulusoy, R. 1990. Two species of whiteflies on citrus in Easten Mediterranean: Parabemisi amyricae (Kuwana) and Dialeurodes citri (Ashmead). Morphology, Biology, Host plants and Control in Southern Turkey. J. Appl. Ent. 110: 471-482.

Walker, J.P., and Zareh, N. 1990. Leaf age preference for oviposition by three species of whiteflies on lemon. Entomol. Exp. Appl. 56: 31-45.

Zanic, K., IgrcBarcic, J., and Kacic, S. 2001. Dialeurodes citri (Ashmead, 1885) in the Adriatic Region of Croatia. Agriculturae Conspectus Scientificus 66 (3): 161-168.

Zhang, Y.H., Liu, C.H., Wang, Q., Zhou, C.Y., and Zhou, Y. 2019. Identification of Dialeurodescitri as a vector of Citrus yellow vein clearing virus in China. Plant Disease 103: 65-68. (https://doi. org/ 10.1094/PDIS05-18-0911-RE) 